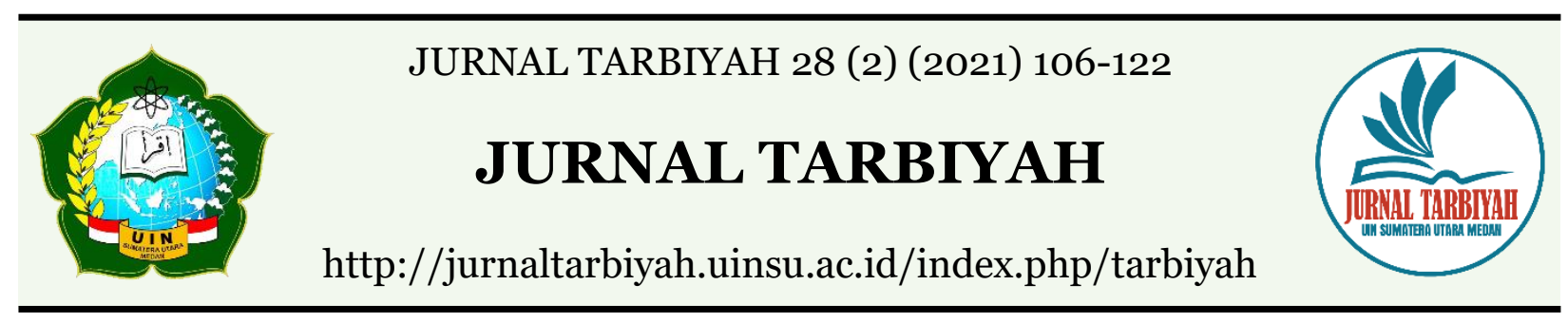

\title{
THE DYNAMIC TRANSFORMATION OF ISLAMIC EDUCATIONAL INSTITUTIONS IN GAYO FROM 1900 TO 1986
}

\author{
Ihsan Harun'1, Indra ${ }^{2}$, Emy Yusdiana 3 \\ 1,2,3Institut Agama Islam Negeri Takengon, Aceh \\ Email: 1ihsan240681@gmail.com, ${ }^{2}$ indra@iaintakengon.ac.id \\ 3emyyusdiana@gmail.com
}

DOI : 10.30829/tar.v28i2.1138

Accepted: November 4th, 2021. Approved: December 28th, 2021. Published: December 30th, 2021

\begin{abstract}
The dynamic development of Islamic education in Gayo cannot be separated from the turbulent period of education in Indonesia in general. The emergence and development and collapse of non-formal educational institutions and the transformation of formal institutions were influenced either directly or indirectly by the renewal of the dynamics of Islamic educational institutions in Indonesia. It was clear that the development of institutional transformation in Gayo from 1900 to 1986 was started by umah education. Graduates of homeschooling education usually continue their education to Mersah (musalla) or joyah for women of Gayo. These educational institutions are known as nonformal education. The formal education from 1900 to 1986 was started by Tarbiyah Islamiyah and Sekolah Rendah Islam (from 1902 to 1940). Meanwhile, in 1970 Pendidikan Guru Agama Pertama was established. Then, in 1980, this institution changed into Madrasah Aliyah Negeri 2 in Takengon. After that, in 1968 IAIN Persiapan was established in Temetas Lemah Burbana as Islamic higher education. However, this institution was transformed into Madrasah Aliyah Negeri 1 in Takengon in 1978. The Higher Education Institution was established in 1986 as a result of the transformation of STIE, STIT, and STIP into Perguruan Tinggi Gajah Putih Takengon. STIT tranformed into STAI Gajah Putih Takengon, and then it transformed into STAIN Gajah Putih Takengon, and today it is known as IAIN Takengon. Meanwhile, the STIE and STP transformed into Universitas Gajah Putih Takengon.
\end{abstract}

Keywords: Transformation, Institution, Islamic Education, Gayo 


\section{INTRODUCTION}

The Gayo and Alas people in Aceh are classified as Melayu Tua tribe. This is described in the saga of the Kings of Pasai. There was a group of people in the country who did not want to convert to Islam, so they live in the headwaters of the Peusangan river which is why they were named the Gayur people. The contact of Islam with the people of Gayo had been started since the entry of Islam in Perlak before 659/1260 (the exact year cannot be traced certainly). The people of Gayo who lived there gradually began embracing Islam. The people living in Gayo mingled with Muslims in the government and the society. Islamic teachings were preached to the Linge Kingdom by Islamic scholars of the Perlak Kingdom. The in that region led a new life in an orderly and peaceful manner because they were bound by the basis of religion and customs in an integrated manner.

This principle is stated in article 45 of the customary law of the Linge Kindom stipulated in the discussion among Merah/Reje (King), Islamic scholars, traditional leaders, and intellectuals after going through a long process of three and a half centuries. This principle can be understood from the traditional sayings "agama urum edet, lagu zet urum sipet, agama ken senuwen edet kin peger" which means "Islamic religion and the tradition of Gayo are like substances and characters, religion serves as a plant, and custom serves as a fence). The entry route of Islam to Gayo is preached through Jambo Aye, Perlak, Kuala Simpang, Wih Jernih, and the Upper Stream of Peusangan River in the Laut Tawar area. The acculturation of Islam with local culture in the people of Gayo is divided into Accommodation, Identification, and Internalization.

The social condition of the Gayo people before and in the era from 1900 to 1986 is not yet clear. The road which was used as a means of trade transportation from Gayo to the coast of Aceh was carried out on food using Among or horses. The travel time was calculated according to the circulation of the sun. In some places, a hut was built, and it functioned as Pemarin (shelter), and in a place that was far away, a Pejamuren (a place to stay) was built. The development of infrastructure in Gayo began when the Dutch took control of the Central Region of Aceh in 1904. Since the opening of the transformation route, socio-economic development has developed in Gayo through the plantation and trading businesses (damar, tea, and coffee plantations) belonging to the Netherlands and Belgium as well as traders and other businesses.

According to the first census conducted in Gayo in 1930, the total population of people in GAyo was 50,676 people. The culture of Gayo people includes language, speech, custom, family, housing, household equipment, carving arts, vocal and dance, 
agricultural tools, business systems, education, honor, mutual assistance, and culture in other aspects of life.

Political conditions in the early 1900 s to 1986 during the colonial period can be seen as follows. The Dutch weakened the potential of Gayo people by emphasizing the Khilafiah and division (clan) towards Independence. The political party upheaval in 1946 changed the political order, including Aceh in general and Gayo specifically which was continued by the PKI and DII/TII movements that also brought impact on society. During the New Order era, the socio-political conditions were also unstable due to the pressure to raise one party from the government and the protracted Aceh conflict over the social order of political conditions. In Central Aceh, there are three places of exile for political opponents, namely Umah Ilang (red house), the Perkebunan Damar, and the Burni Telong.

In the context of Gayo civilization, the intellectual activities from 1900 to 1986 lasted a long time in different models and styles, including scientific research or advanced studies at well-known educational centers at that time, including the tradition of writing and the establishment of Islamic educational institutions. The destination of Islamic education from 1900 s to 1986 in Pulo Kitun, Cet Merak, and Samalanga located on the peninsula of the East coast of Aceh became a study center that was admired as proud of. In addition to the study center, Thawalib Sumatera Barat became famous at that time among the people of Gayo. Finally, the educational center also greatly influenced the world of Gayo Islamic education, namely Bangil.

\section{RESEARCH METHOD}

This study follows the historical research method which is used to investigate a problem by applying a solution from a historical perspective. Historical research is an instrument used to reconstruct historical events (history as past actuality) into written history. According to March Bloch, history is the science of change, or in other words, history is a process, not a structure. The historical research method is used as a guide in researching historical events and historical issues. Meanwhile, the approach used is a social history approach in which it pays important attention to non-elite elements of a society that is discussed and considers other factors outside of political factors. By using this historical method, it is expected that precise and accurate information can be obtained regarding the political, religious, social, and intellectual background of education, the key figures of Islamic education and contributions to Islamic education, 
the development of Islamic educational institutions, and the development of Islamic education networks in Gayo from 1900 to 1986.

The data of this study were collected by using several methods including 1) Multimethod to collect data by observations, interviews, intelligence analysis, field observation, and additional techniques as strategies applied to the research objects; 2) Entry into the field; 3) Participant Observation 4) In-depth Interviews; 5) Document and artifact collection; 6) Field observations; 7) Supplementary techniques. Furthermore, several techniques were used to collect the data including visual techniques, non-verbal communication analysis, measurements, special surveys, and library studies.

Historical Analysis was used to analyze the data. This refers to the theory of Mc Millan and Schumacher as well as the theory of Noto Susanto, namely 1) Inductive analysis and overview, 2) Analysis of findings in the field, 3) Coding topics and categories, 4) Patterns, 5) Manual and computer for analysis data. To fulfill the steps in this historical research, the researchers follow the data analysis techniques that refer to Noto Susanto including heuristics, criticism, interpretation, and historiography. These were used to see the development of Islamic educational institutions and the development of Islamic education networks in Gayo from 1900 to 1986.

\section{The Dynamics of Islamic Education Institutions in Gayo from 1900 to 1986}

Looking at the history and development of Islamic education in Indonesia, the reformation of Islamic education in Indonesia is by the current of renewal in the Islamic world in the nineteenth century starting from Egypt, Turkey, India, and Indonesia. These reform ideas entered the world of Islamic education in Indonesia. Several aspects of education have become the cause for the renewal, including aspects of subject matter, methods, and the education system.

Referring to Aceh in the age of National Awakening from 1908 to 1942, the history of Aceh in general and especially Gayo in the early period of 1900 to 1986 can be considered interesting. Besides still fighting against the Dutch, the people of Aceh/Gayo were also acquainted with one of the elements of Western culture, namely modern education which resulted in various changes in society. Gayo was the last area colonized by the Dutch in September 1901 while Aceh, in general, had been colonized since 1873 . However, in 1873 the Dutch began to record the area and inland inhabitants of Aceh because this area was used as a hiding place and a source of logistics by Islamic scholars, Acehnese leaders, and fighters to fight the Dutch aggression. 
The Dutch ran the colonial rules through traditional institutions to include these institutions in a modern bureaucratic structure. Besides Uleebalang with modern education, the people also need to increase their intelligence through village schools to be able to write, read and count. With education, the Dutch were sure that the people will not follow the call as religious leaders to fight the Dutch colonial government. Based on this consideration, the Dutch saw the importance and function of the Uleebalang/ Reje in smoothing out their colonization in Aceh. During the Dutch period, there was discrimination in the admission of students to school. Generally, the opportunity to study in Dutch-speaking schools and to continue to higher-level education was given to children of the Uleebalang/Reje.

Aceh-Gayo during the Japanese colonization period (1942 - 1945) faced another problem. At this time, education, in general, experienced a decline compared to education at the end of the Dutch colonial era. At the end of the Dutch colonial era, there were various types of education, such as general education organized by the government, starting from Volkschool (Village Schools) in the villages to MULO in Kutaradja (Banda Aceh). In addition to schools run by the government, at this time there were also privately run schools such as Muhammadiyah, Taman Siswa, and other local community business schools, such as Pasuka Pereulak, Rumah Perguruan Kita, and Rumah Perguruan Murid in Takengon.

When Aceh was under Japanese rule, the development of education declined. At this time, people were not allowed to go to private secondary schools at all. There were only two public secondary schools, namely Shu Gakko (five-year high school) with a Japanese principal named Hashimoto and Indonesian teachers such as Karim Duriat, Suratno, Ali Murtolo, Mukman S Burhanuddin Pasaribu, Hasjim MK, and A. Azizs Ibrahim. Another school was called Sihang Gakko (Three-year school for teachers). This school was also led by Japanese people, and the teachers include Burhanuddin Harapan and Ibrahim. In the field of elementary education, all schools left by the Netherlands were turned to be Kokumin Gakko (Public Schools) with six years of studying period, the language used was Japanese while Dutch and English were omitted. The Arabic-Malay letters were replaced by Japanese letters (Katakana and Hirakana). Japanese songs, such as KimiGayo and Taiso (Morning Gymnastics) were taught to every student at school. Students at school were told to make gardens, they worked together to build roads and drainage. Education at that time was rather focused on the military field, and Japan hoped the young generation of Indonesia could help them in dealing with the war. To regulate educational 
issues, the government established an educational office called Bunkyoka to regulate teaching throughout Aceh which was domiciled in Kutaraja.

Education in Aceh / Gayo in the age of Independence (1945 - 1977) was not very good, it was estimated that $93 \%$ of the total population of Indonesian was illiterate. The Aceh region was one of the most degenerate (lagging) regions in the field of education. By the historical development of Aceh, which was the last area controlled by the Dutch, in terms of introduction to the general education system (western education), the Aceh area was the slowest area to be influenced by Western education. Indeed, there is an opinion that the people of Aceh used to be very reluctant to go to public schools because of the assumption that those who speak Malay will become infidels (kaphe).

Aceh in the middle of the conflict period (1976 - 2005), instead of building Aceh and catching up, especially education in Aceh, in 1976 Aceh was again in turmoil as a result of the Gerakan Aceh Merdeka (GAM). This is a separatist organization that aims to separate Aceh from Indonesia. The conflict between the Indonesian government and GAM caused the death of almost 15,000 people. In addition to the loss of life, educational facilities and infrastructure were also the impacts of the conflict. The number of educational institutions was burned down and the anxiety and fear of going to school became a separate problem. As a result, many Acehnese children dropped out of school. This movement is also known as the Aceh Sumatra National Liberation Front (ASNLF). GAM was led by Hasan di Tiro for nearly three decades living in Sweden and was a Swedish citizen. On $2^{\text {nd }}$ June 2010, the status of Indonesian citizenship was obtained.

In the period from 1967 to 2005, Aceh was still in a situation of prolonged conflict, of course, the situation was not conductive and not safe greatly affected the education of the Acehnese people. Although during that time Aceh could not be separated from discussions and debates about the direction of Indonesia's reform in 1998. If Indonesia was faced the struggle to face the reformation era, fill out and complete the reformation agenda, then Aceh at that time struggled with the reform mission and faced a period of conflict that never comes. This situation was certainly not in Aceh's favor to look for a better future as what was expected from the reformation agenda itself.

Based on the periodization of educational upheaval in Aceh since the Dutch and Japan colonization, the independence period which consisted of the old and new orders era, and then the DI/TII upheaval, the prolonged Aceh Conflict which lasted until the end of the 1900 to 1986 era brought a very significant impact for the development of Islamic education in Aceh in general and Gayo in specific. 
Therefore, unraveling the development of Islamic education in Gayo cannot be separated from the period of educational turbulence in question, the emergence and development as well as the collapse of non-formal and formal educational institutions which were caused indirectly or directly by the turbulent development of Islamic education in Gayo from 1900 to 1986. Thus, based on this, the development of Islamic education in Gayo from 1900 to 1986 can be described in the form of non-formal and formal education.

\section{Non-formal Education}

The lowest Islamic educational institution that can be found in Gayo from 1900 to 1986 was given at home. The Muslim community of Gayo uses their house as a non-formal lower educational institution. Graduates from home education usually continue their education to a Mersah (musalla) as another non-formal Islamic educational institution. Teacher or what was called Tengku taught students to read hijaiyah letters, to read the Qur'an, and taught the students basic knowledge of the Islamic faith in this educational institution.

In 1935, a Tengku (teacher) named Tgk. Ibrahim taught Islamic faith at his home in Bebesen. The students who attend this educational institution were generally the children of the Tengku's neighbors, apart from their own families. Another teacher who taught at his home was Tgk. Abdurrahman Semaun in Bebesen.

As a non-formal educational institution, there was no age limit for students to study Islamic education at Tengku's house or in Mersah. However, since the students continued their education to Mersah or Islamic lower education after studying from home education, it can be assumed that the age of the students was below 13 years old. Mr. Abdul Kadir, a well-known figure in Gayo started learning in Mersah at the age of 10 years old. Although some students were teenagers, $\mathrm{Mr}$ Ibrahim taught them at his home.

It is understood that the house served as a place of education has existed before the 1900 s to 1986 . It can be seen from the existence of other non-formal institutions that had existed since the $19^{\text {th }}$ century AD, namely Meunasah or Mersah and Mosques. Before the 1903s, the Quba Mosque, a mosque in Bebesen had carried out non-formal Islamic education. In another location, in Bur Biah, Tgk. Kali taught how to read the Qur'an, Bidayah book, and Perukunan in Mersah (musalla) in Dah, and because of this, the teacher was called as Tgk Kali Dah. Tgk. Ibrahim who later 
taught the Qur'an and the basics of Islamic faith received education at the Mersah (musalla) Bur Biah from Tgk. Kali Dah, his father. Tgk. Muhammad Ali was also known to carry out Islamic education in Mersah (musalla) of the Egyptian village in 1905. In Buntul Temil, in the Asir-Asir on the shores of Lake Lut Tawar, right beside the Peusangan River, Tgk. Abdul Karim was also called Tgk. Paya carried out Islamic education at the Buntul Temil Mosque. In Kebayakan, it was known that Tgk. Khatib also taught the lessons related to the Qur'an in Mersah (Musalla) of Kebayakan in 1925, and Tgk. Kadhi also taught at the Mersah (Musalla) in Kenawat in the same year. Also, Tgk. Abdurrahman taught in Mersah (musalla) Batin in Kebayakan and Meunasah in Pegasing.

As a non-formal institution of Islamic education, the education is given in Mersah (Musalla) also did not aim for a definite time in learning. New students were said to have graduated when they mastered the lessons taught, in general, the reading of the Qur'an. Tgk. Abdul Kadir (Tgk. Pasir) received 5 years studying period in Mersah (musalla) from 1920 to 1925, from the age of 10 to 15 years old.

The procedure for implementing education in Mersah (musalla) was traditional in that the students gathered and sat in front of the Tengku. There were no chairs, blackboards, or other learning facilities like what was prepared in modern schools. Later, some educational institutions in Mersah (musalla) transformed into more modern educational institutions and carried out higher levels of education in the form of boarding schools. A transformation that can be traced back occurred in 1927 when the Mersah institution (musalla) in Kenawat was led by Tgk. Kadhi Ramhak became a Kenawat boarding school.

The books studied by the students in Meunasah education were Bidayah and Perkununan. Bidayah was a book which is also not certain whether it was the Bidayatul Mujtahid written by Ibn Rushdi in the field of comparative jurisprudence or Bidayah wa Nihayah written by Ibn Katsir or Bidayatul Hidayah written by alGhazali. Meanwhile, the book called Perukunan refers to two books of reconciliation which were written by Shaykh Jamaluddin al-Banjari or Fatimah bint Abdul Wahab Bugis.

In the Islamic education system carried out at Mersah (musalla) in Gayo, the term "Kejurun" (region) was known. Takengon itself was divided into four Kejurun (region), namely Bebesen, Linge, Bukit and Syiah Utama. Every Kejurun usually has 
one mosque that carried out Islamic education in addition to various Mersah (Musalla) in a smaller scope.

Islamic educational institutions for women in Gayo had their places for studying. The movement of women in developing education in Gayo can be seen from the existence of an institution known as Joyah. The term "Joyah" comes from the word Zawiyah which is one of the non-formal institutions in Gayo. Joyah is a small building as a part of Mersah that functions as a place of learning for women. Each of Joyah has a Tengku Banan (female religious teacher). Joyah's main activity is to teach the students to learn how to read the Qur'an, understand its meaning, and learn laws related to worship.

From early 1900 to 1986 until the middle era, Joyah's role was still visible in the Gayo community and was seen in almost every Kejurun and Belah in Gayo. People's attentio was often attracted by Joyah Toa and Joyah Uken. Joyah Toa was located in the eastern of Bebesen village while Joyah Uken was located in the west of the Bebesen village. Today, one of the Joyah can be seen, but it is more modern in its management.

\section{Formal Education}

\section{Basic Islamic Education Institute}

Basic Islamic educational institutions have existed since 1902; Tgk. Abdurrahim Daudy has established a formal Islamic educational institution iin Buntul Batin Kebayakan. After that, he worked with Tgk. Abdul Karim transform the institution into a boarding school known as Tarbiyah Islamiyah.

In 1935 Madrasah Ibtidaiyah (now it is equivalent to Raudatul Atfal or Islamic Kindergarten) was established in Ujung Kebet This madrasa was established as a continuation of non-formal education conducted in Mersah, specifically this functions as the continuation of non-formal education carried out by Tgk. Abd Karim. Tgk. Abd Karim (Tgk. Paya) himself was one of the important figures in the establishment of this first Islamic Madrasah.

Students who enrolled in SRI were students who have learned in Islamic education in Tengku's house or Mersah. Therefore, the age of students attending the SRI institution was around 7 years old or over. However, the students could be younger than that. From the historical record, Tgk. Mahmud Ibrahim, a student at Madrasah Ibtidaiyah in Ujung Kebet was enrolled into the institution at the age of 5 
after attending Islamic education at his father's house and was the youngest student at that time.

Madrasah Ibtidaiyah in Ujung Kebet Paya Ilang was led by Tgk. Abdul Karim Hasan Gayo. The teachers who taught at this institution were Tgk. Muhammad Ali Berawang Remang and Tgk. Khalidin, in addition to Tgk. Abdul Karim Hasan Gayo. The subjects taught were Arabic by using the rote method. Various basic vocabularies were taught, such as Kitabun (book), lauhatun (slate), finsilun (pencil), and other words. Students' graduation in their final year refers to an open oral exam. The student being tested takes his place in a pulpit (such as the Friday sermon pulpit) in front of the teacher as the examiner who then asked questions orally. Students' graduation was announced right away while the students were still on the pulpit.

The next level of Islamic education was carried out by Sekolah Rendah Islam. In Gayo, Takengon, the first Sekolah Rendah Islam was established in 1946 to 1947 in Buntul Temil Asir-Asir. The school later transformed into Madrasah Ibtidaiyah Negeri Asir-Asir. The teachers included Tgk. Abd Latif Rosydi, Tgk. Banta Cet Toweran, Tgk. Syahrun Langkat Asir-Asir, Tgk Abu Bakar Mizan, Tgk. Muhammad Yacob, Tgk. Sulaiman, Tgk. Ilyas Lebe, Tgk. M. Saleh Adri, Tgk. Mohd Ali Diadun. One of the lessons taught in this institution was basic Sufism. This school was established by an educational institution known as Mersah Asir-Asir. In 1947, Tgk. Banta Cet Toweren who was also a teacher in SRI Buntul Temil Asir-Asir initiated a non-governmental organization to build another SRI namely SRI Bom The location was the former Indonesian soldiers' camp in Bom. The community built the building, provided sand from the Peusangan river, a roof is taken from a former sugar factory that was not operating, mountain stones, and other materials. The Central Government of Aceh which has just been formed in 1946 did little to help to build SRI Bom because of the struggle against Dutch aggression in that supplies and soldiers were sent to Langkat, Medan, and Karo. It was only in 1948 that SRI was officially established and accepted the first students.

The first batch of SRI Bom consisted of students who were transferred from SRI Buntul Temil. Tgk. Banta Cet Toweren who was a teacher at SRI Buntul Temil certainly used the model of SRI Buntul Temil in SRI Bom. SRI Bom transformed into Madrasah Ibtidaiyah Negeri 1 in 1959, which is 13 years since its establishment. In 1959, Indonesia established several Islamic basic educational institutions 
simultaneously in Takengon, Central Aceh. In addition to the transformation of SRI into MIN 1 Takengon, MIN 2 Takengon, MIN Toweren in Toweren, and MIN Rawe in Rawe, MIN 1 Kebayakan, MIN 2 Bebesen in Ujung Gergung, MIN Simpang Kelaping and MIS Muhammadiyah Kebayakan.

Other schools also began to be established in Hakim Bale Bujang village in 1935 under the name Pendidikan Islam (PI). The main founder is Tgk. Abdul Jalil. This school continued to be active until 1980. At the same time, in 1936, Tgk. Abdul Rahman found and managed another educational institution called Tarbiyah Islamiyah at Simpang Empat Bebesan. This school later transformed into Sekolah Rendah Islam (SRI) under the Ministry of Religion of the Republic of Indonesia in 1950. Today the school has been transformed into Madrasah Ibtidaiyah 8 at Simpang Empat Takengon.

Before establishing and managing the Tarbiyah Islamiyah, Tgk. Abdul Rahman helped Tgk. Damanhuri (Tgk. Silang) in managing the Tarbiyah Islamiyah in Batin Kebayakan. Similar to SRI, in Kenawat, an Islamic educational institution was established Kenawat in 1927, and this institution was known as the Kenawat boardingschool led by Tgk. Kadhi Rampak. This institution was one of the most wellknown Islamic formal educational institutions at that time. Initially, this boarding school was a Mersah educational institution that was managed by Tgk. Kadhi Rampak. It was only in 1927, this institution was transformed into a more modern educational institution where students sat on chairs to attend a lesson. Many alumni from the Kenawat Boarding school continued their education to Pulo Kitun Bireuen. Some of the famous alumni of this institution were Tgk. Ilyas Leube, Prof. Dr. Mr. H. Baihaqi, A.K., and Drs. Tgk. H. Ali Hasyim.

In 1942, Tgk. Abdul Kadir established a boarding school in Kebayakan. He was a student (1925 - 1927) and a teacher at the Kenawat boarding school from 1927 to 1942. He adapted the Kenawat boarding school as a model for Kebayakan in which was managed as a modern educational institution whose teaching process took place in the classroom.

After a long time, there was no establishment of a new Islamic educational institution. This was caused by the political upheaval in the central Aceh region, namely the DII/TII rebellion, the Gerakan Aceh Merdeka (GAM). Then in 1985, other basic Islamic educational insitutions were established in Central Aceh, namely 
MIN Kenawat Lut, MIN 1 Bebesen, MIN Berkemas, MIN Uning, MIN Jagong, MIS Ratawali, MIS Ujung Temetas.

The rapid development of Islamic basic educational institutions in Central Aceh subsequently occurred at the end of 1900 to 1986 in which 6 state Islamic basic educational institutions were established in 1997, namely MIN Gunung Bukit, MIN Gelelungi, MIN Remesan, MIN Pepayungan, MIN Arun Kumer and IN Star.

\section{Secondary Educational Institution}

In Takengon, Madrasah Tsanawiyah was first established on April 25, 1960 in Bom which later turned into Madrasah Tsanawiyah Negeri Bom in 1965. Five years later, in 1970, Pendidikan Guru Agama Pertama (PGAP) was established in Blangkolak as the first Islamic educational institution that carried out higher Islamic education. In 1980, this institution changed into Madrasah Aliyah Negeri 2 Takengon.

Then, in 1968, the IAIN Persiapan in Temetas Lemah Burbana was established to provide Islamic higher education. However, this was transformed into Madrasah Aliyah Negeri 1 Takengon in 1978. In addition, in 1978, other Islamic educational institutions were established, namely MTSN 1 Takengon, and MTSN 2 Takengon.

Furthermore, in 1985, another Islamic educational institution was established, namely MTSN Angkup. Further developments can be referred to at the end of 1900 - 1986 when MTSN Jagong was established, MTS and MAS Darul Mukhlisinin in Bebesen was established in 1993, MAS Ulumul Qur'an was established in 1998, MTSN Ratawali and MAN Pegasing were established in 1999. MTS and MAS Darul Mukhlisin were institutions transformed from the Darul Mukhlisin Islamic boarding school that was established in 1989.

\section{Islamic Higher Educational Institution}

The efforts made by the people of Central Aceh to have an Islamic educational institution came into realization in 1986 due to the enthusiasm of the community to continue their studies to a higher level and the limited funds from some people to continue their children's studies and move from the desire to participate in national development. Various components of the Gayo Highlands 
community in collaboration with the regional government of Central Aceh seek to improve the quality of human resources on an ongoing basis.

The idea of establishing higher education began in 1984 from the thoughts of Mahmud Ibrahim, Harun Ugaty, and Ja'far Ismail. The Regent approved the idea and submitted a plan to the Regional House of Representatives for Central Aceh regency and issued a decree number 421.4/o6/1984 on 28 July 1984 concerning the Establishment of a Higher Education in Central Aceh signed by the Head of Dewan - Kapten Abdullatief.

Following up on this idea, several meetings attended by leaders were conducted in the Operation Room of the Regional Secretariat of Central Aceh on December 1, 1984, to discuss and formulate the program and budget for the implementation of the committee's duties. Regent Lt. Col. M. Benni Banta Cut was also present at the deliberation. The second committee meeting was held at the Office of the Regent of the Regional Head in Level II in Aceh Tengah on 19 January 1986 at 22:00 pm to 24.00 Indonesian western times. This meeting was attended by the regent - Letkol M. Djamil, Drs, M. Syarif, Drs. Mahmud Ibrahim, Harun Ugaty, Drs Arifin M.R. Banta Cut, Kadim of the head of the social and political office, A.S. Kobat, Amin TH. BA, Ir. Zainal Abidin, A. Kobat and Matsyam. During the meeting, the preparations for Higher Education and Cultural Arts Institute were discussed as the results of an international seminar on Science and Culture held at the Takengon Arts Building in 1984.

Since the beginning of its transformation, the administrators of the Yayasan Gajah Putih has made several breakthroughs that were oriented towards the realization of reliable and dynamic quality of human resources in Gayo highlands. The Yayasan Gajah Putih proved its efforts with the establishment of the three high schools of Gajah Putih and three high schools in Aceh Tengah, namely Sekolah Tinggi Pertanian Gajah Putih, Sekolah Tinggi Ilmu Tarbiyah (STIT) Gajah Putih, Sekolah Tinggi Ilmu Ekonomi (STIE) and Sekolah Menengah Atas Gajah Putih.

Sekolah Tinggi Ilmu Tarbiyah (STIT) under the Yayasan Gajah Putih Takengon was established in 1986 with the operational permit of Kopertais Region V Aceh. Sekolah Tinggi Ilmu Tarbiyah Gajah Putih has two departments, namely Pendidikan Agama Islam (PAI) dan Pendidikan Bahasa Arab (TBA). Both majors were held based on the Decree of the Minister of Religion of the Republic of Indonesia Number 256 of 1989 on 121989 with the registered status. The 
registered status was extended again through the Decree of the Minister of Religion Number 24 of 1995, on June 161995 and it was valid until 1999. In 2000, the Studi Pendidikan Agama department at the Department of the Tarbiyah Science College (STIT) Gajah Putih received the status of Recognized based on a Decree DirectorGeneral of the Ministry of Religion of the Republic of Indonesia Number E/93/2000 on June 262000.

Overtime, the STIT of Gajah Putih then transformed into STAI Gajah Putih in Takengon. In 2012, STAI Gajah Putih was transformed into STAIN Gajah Putih based on the Presidential Regulation Number 50 of 2012 concerning the Establishment of the Sekolah Tinggi Agama Islam Negeri (STAIN) Gajah Putih TAkengon in Aceh Tengah. In 2020, the STAIN Gajah Putih Takengon transformed into Institut Agama Islam Negeri (IAIN) Takengon based on Presidential Regulation Number 4 of 2020 concerning the Institut Agama Islam Negeri (IAIN) Takengon.

Jaringan Lembaga Pendidikan Islam di Gayo Era Tahun 1900 - 1986

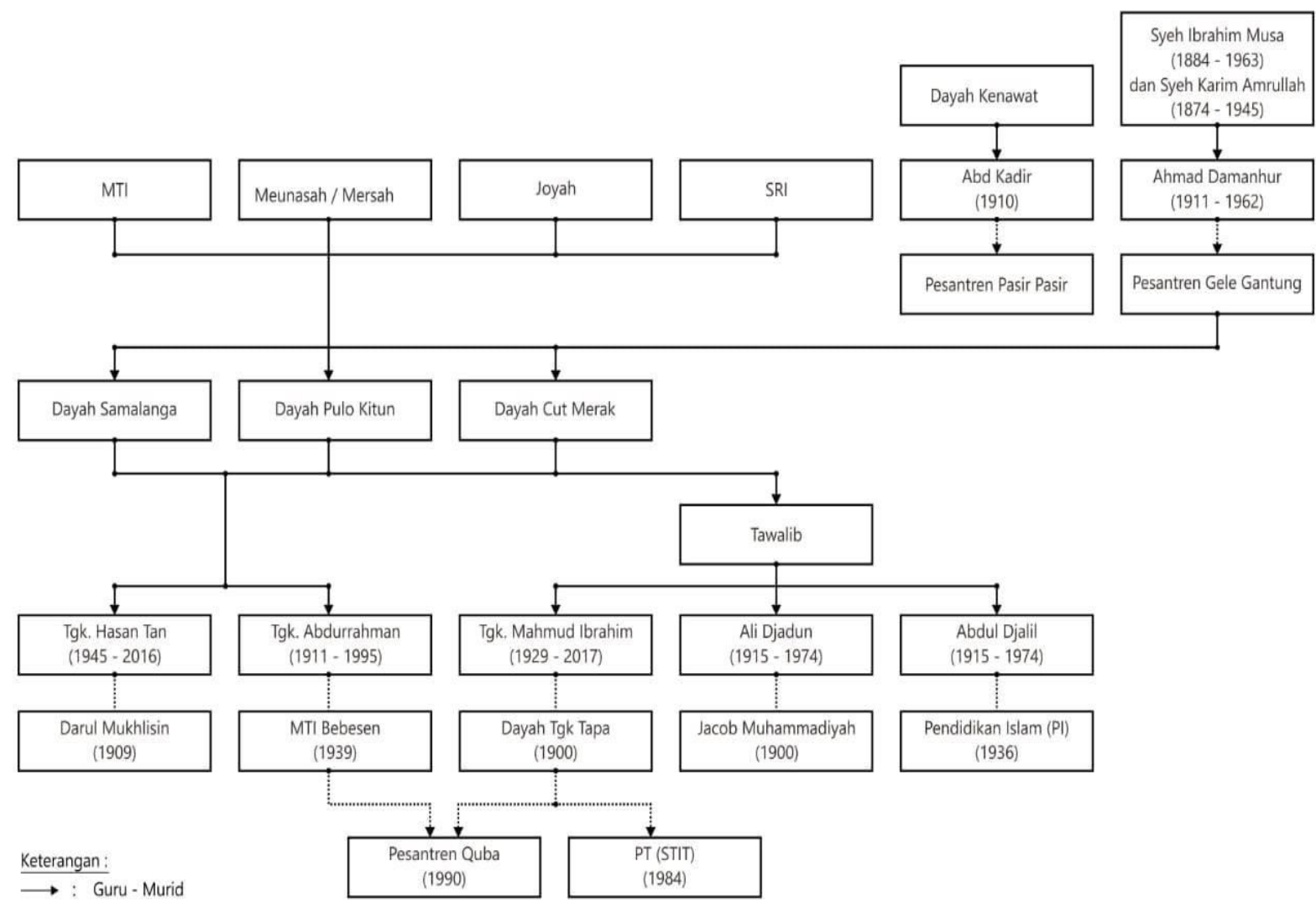

Picture 1. Dynamics of Islamic education in Gayo from 1900 to 1986 
However, Islamic education in Central Aceh has stronger roots than general education. Public educational institutions only entered Central Aceh through Dutch influence in 1904. Not long after 1904, the Voor Poolks School in Simpang Lima was established. Then it was followed by Voor Poolks School in Simpang Empat, Mampak Kebayakan Tingkem, Nosar, Ketol and Blangkejeran. This institution later transformed into Sekolah Rakyat after the independence of Indonesia, and it changed its name to Sekolah Dasar Negeri up to these days. The dynamics of Islamic education in Gayo from 1900 to 1986 can be illustrated in the picture 1.

\section{CONCLUSION}

The dynamics of the development of Islamic education in Gayo cannot be separated from the turbulent period of education in Indonesia in general. The emergence and development and the collapse of non-formal educational institutions and the transformation of formal institutions were caused either directly or indirectly $y$ the renewal of the dynamics of Islamic educational institutions in Indonesia.

The development of the dynamics of Islamic educational institutions in Gayo is visible in the institutional transformation from 1900 to 1986 which began with Umah education. Graduates from home education (Umah) usually continued their education to Mersah (musalla) and Joyah for Gayo women's education. These educational institutions were known as non-formal educational institutions.

From 1900 to 1986, the formal education was started by Tarbiyah Islamiyah and Sekolah Rendah Islam (SRI) (1902 - 1940s), and many other institutions were established in the half of the 1950s Tarbiyah Islamiyah and Sekolah Rendah Islam (SRI) then this was transformed into Madrasah Ibtidaiyah.

Meanwhile, at the secondary level, in 1970 Pendidikan Guru Agama Pertama (PGAP) was established, and in 1980, this institution transformed into Madrasah Aliyah Negeri 2 Takengon. Then, in 1968, the IAIN Preparation was established in Temetas Lemah Burbana to organize Islamic higher education. However, in reality, it was transformed into Madrasah Aliyah Negeri 1 Takengon in 1978.

At the higher education level, the higher educational institution in Gayo was only realized in 1986 due to the enthusiasm of the community to continue their studies into a higher-level education. It was also caused by the limited funds of some people to continue their children's studies and move from participating in national development. Various 
components of the Gayo highlands community in collaboration with the regional government of Central Aceh regency seek to improve the quality of human resources on an ongoing basis. The establishment of the higher educational institution in Gayo which was known as the Perguruan Tinggi Gajah Putih which was at that time led to the STIE, STIT, and STIP.

Sekolah Tinggi Ilmu Tarbiyah (STIT) was under Yayasan Gajah Putih Takengon which was established in 1986 with the operational permit of Kopertais in Region V of Aceh. Sekolah Tinggi Ilmu Tarbiyah Gajah Putih has two departments, namely Pendidikan Agama Islam (PAI) and Pendidikan Bahasa Arab (TBA). Both majors were run based on the Decree of the Minister of Religion of the Republic of Indonesia Number 256 of 1989 on 12 September 1989 with the registered status. The registered status was extended again through the Decree of the Minister of Religion Number 264 of 1995 on 16 June 1995 and was valid until 1999. STIT then transformed into STAI in the second half of 2000, then it transformed into STAIN in 2012 and is currently IAIN Takengon.

\section{REFERENCES}

Abdurrahman, Dudung Metode Penelitian Sejarah (Ciputat: Logos Wacana Ilmu, 1999) Asari, Hasan Menguak Sejarah Mencari Ibrah: Risalah Sejarah Sosial-Intelektual Muslim Klasik (Bandung:Citapustaka Media, 2006)

C.L, School en Huwelijk op Atjeh, Tijdschrift voor Bin-nenlandsch Bestuur (TBB)

Daulay Haidar Putra, Dinamika Pendidikan Islam ( Bandung: Cipta Pustaka Media, 2004)

Hurgronje C. Snouck, Gayo...

Ismuha, Pendidikan Agama di Aceh, prasarana diskusi MSI-Aceh (Banda Aceh: Kanwil departemen P dan K Aceh-MSI Aceh, 1977)

Ibrahim dkk Muhammad, Sejarah Daerah Propinsi Daerah Istimewa Aceh ( Jakarta: CV.Tumaritis cet II, 1991)

Kremer J., Atjeh (Leiden : EJ.Brill, Cet II 1992)

Kuntowijoyo, Metodologi Sejarah (Yogyakarta: PT. Tiara Wacana Yogya, Edisi Kedua)

Mahmud Ibrahim, Mujahid Dataran Tinggi Gayo (Takngon:Yayasan Maqamam Mahmuda, 2007)

Nayan, Majalah Minami,

Pieaker A.J., Atjeh en de Oorlog met Japan (Den Haag-Bandung: W.Van Hoeve, 1949) 
Ihsan Harun, Indra, Emy Yusdiana/ JURNAL TARBIYAH 28 (2) (2021) 106-122

Schumacher Sally and James H. McMillan Research in Education, A Conceptual Introduction, edisi ke-5 (New York: Priscilla McGeehon, 2001)

Undang-Undang Tentang Sistem Pendidikan Nasional (UU Rl No. 2 th 1989) dan Peraturan Pelaksanaannya (Jakarta: Sinar Grafika, 1993)

10 Tahun Darussalam dan Hari Pendidikan, (Banda Aceh: Yayasan Pembinaan Darussalam, 1969) 